\title{
Detection of hepatopancreatic parvovirus in Thai shrimp Penaeus monodon by in situ hybridization, dot blot hybridization and PCR amplification
}

\author{
Jurairat Phromjai, Vichai Boonsaeng, Boonsirm Withyachumnarnkul, Timothy W. Flegel* \\ Centex Shrimp, Chalerm Prakiat Building, Faculty of Science, Mahidol University Rama VI Road, Bangkok 10400, Thailand
}

\begin{abstract}
Hepatopancreatic parvovirus (HPV) infects the hepatopancreas in penaeid shrimp and retards their growth. The DNA sequence of HPV from Thai shrimp Penaeus monodon (HPVmon) differs from HPV of Penaeus chinensis (HPVchin) by approximately $30 \%$. In spite of this difference, commercial PCR primers (DiagXotics) developed from HPVchin to yield a $350 \mathrm{bp}$ PCR product do give a $732 \mathrm{bp}$ product with HPVmon DNA template. On the other hand, the sensitivity of HPVmon detection with these primers and with hybridization probes designed for HPVchin is significantly lower than it is with HPVchin. To improve sensitivity for HPVmon detection, we used the sequence of the 732 bp HPVmon PCR amplicon described above to develop specific PCR primers (H441F and H441R) and hybridization probe. The primers could detect as little as $1 \mathrm{fg}$ of purified HPVmon DNA while the $441 \mathrm{bp}$ digoxygenin-labeled PCR product gave strong, specific reactions with in situ hybridization and with hybridization blots. In contrast, negative results were obtained using DNA from all other pathogens tested and from DNA of P. monodon. Supernatant solution from boiled, fresh shrimp fecal and postlarval samples homogenized in $0.025 \%$ $\mathrm{NaOH} / 0.0125 \%$ SDS could be used to detect as little as $0.1 \mathrm{pg}$ HPVmon DNA by the PCR reaction. By dot blot hybridization, a visible signal was obtained with purified HPVmon DNA at $0.01 \mathrm{pg}$, but detection in spiked feces and postlarval samples was only 1 and $0.1 \mathrm{pg}$, respectively.
\end{abstract}

KEY WORDS: Hepatopancreatic parvovirus $\cdot$ HPV $\cdot$ Penaeus monodon · Fecal sample $\cdot$ PCR $\cdot$ Dot blot hybridization · In situ hybridization

Resale or republication not permitted without written consent of the publisher

In Thailand, hepatopancreatic parvovirus (HPV) was first reported in cultivated Penaeus monodon (HPVmon) in 1992 (Flegel et al. 1992). It has since been reported that infections of HPV are related to retarded growth in P. monodon (Flegel et al. 1999) and a high

${ }^{*}$ Corresponding author. E-mail: sctwf@mahidol.ac.th prevalence of small shrimp in rearing ponds can dramatically decrease farm profits. As a result, it has been recommended that postlarvae (PL) be screened for HPV before stocking ponds and that they be rejected if the virus is present (Flegel et al. 1999).

HPV detection was traditionally dependent upon the histological demonstration of characteristic nuclear inclusions by H\&E staining (Lightner 1996) but more rapid, non-destructive molecular techniques have recently been developed (Mari et al. 1995, Pantoja \& Lightner 2000, 2001) and some of these have been commercialized by DiagXotics, Wilton, CT, USA. The commercial PCR primers and hybridization probe for HPV were based on DNA from HPV that infected Penaeus chinensis (HPVchin). The expected PCR amplicon was 350 bp. However, with HPVmon the primers yielded a 732 bp amplicon that had sequence identity of approximately $70 \%$ to the sequence of HPVchin (Phromjai et al. 2001). Due to this sequence difference, detection sensitivity of the commercial primers and probe for HPVmon were reduced. To improve detection sensitivity, we used the cloned and sequenced 732 bp PCR amplicon obtained from HPVmon (Phromjai et al. 2001) to develop and test PCR and hybridization protocols for HPVmon in feces and PL. This method was originally developed in 1999 (Phromjai 1999) and has been in continuous use for HPVmon detection in Thailand since then, although it is being reported here for the first time.

Materials and methods. Optimization of PCR conditions: PCR primers were designed using DNASIS 7 and OLIGO version 4.0 primer design software with the published sequence (GenBank AF456476) for HPVmon (Phromjai et al. 2001) and synthesized by Biosynthesis. The primers H441F (5' GCA TTA CAA GAG CCA AGC AG 3') and H441R (5' ACA CTC AGC 
CTC TAC CTT GT 3') were designed to yield a PCR product of $441 \mathrm{bp}$. Optimization of PCR conditions was carried out in $50 \mu \mathrm{l}$ reaction mixtures containing $1 X$ PCR buffer, $200 \mu \mathrm{M}$ each of dATP, dTTP, dCTP and dGTP, 1.25 units of Taq DNA polymerase, $0.4 \mu \mathrm{M}$ of each primer H441F and H441R, and 100 pg of HPV DNA. The optimal conditions were tested by varying the primer concentration $(0.05,0.1,0.2,0.4,0.6$ and $0.8 \mu \mathrm{M}), \mathrm{MgCl}_{2}$ concentration $(0.5,1,1.5,2,2.5,3$ and $5 \mathrm{mM})$, annealing temperature $\left(50,55,60\right.$ and $\left.65^{\circ} \mathrm{C}\right)$ and PCR cycle number $(20,25,30,35$ and 40 cycles).

PCR specificity for HPV DNA detection: Specificity for detection of HPV DNA was determined using optimized PCR conditions with different sources of template DNA including those from HPV (100 pg), white spot syndrome virus (WSSV, $10 \mathrm{ng}$ ), infectious hypodermal and hematopoietic necrosis virus (IHHNV, 1 ng), HPVmon (10 ng), Vibrio parahemolyticus (10 ng) and HPVchin (DiagXotics, positive control). For electrophoresis, $10 \mu \mathrm{l}$ of each PCR reaction mixture was run simultaneously in a $1.2 \%$ agarose gel in TBE and visualized under UV light after ethidium bromide staining.

Sensitivity of HPV DNA detection by PCR: To determine sensitivity, purified HPV DNA was 10-fold serially diluted (100 pg to $0.01 \mathrm{fg}$ ), used as the DNA template for PCR and products were detected as described above.

Specific labeling of HPV DNA by PCR: Purified HPV DNA or a recombinant plasmid containing an insert of the $732 \mathrm{bp}$ HPVmon amplicon (Phromjai et al. 2001) was used as the template for PCR labeling of the 441 bp amplicon with digoxygenin (DIG) (Genius ${ }^{\mathrm{TM}}$ kit, Boehringer Mannheim). The reaction mixture contained HPV DNA or plasmid, deoxynucleotide triphospate including DIG-dUTP and other necessary components required by conventional PCR. The amplification was carried out under optimized PCR conditions with the reaction mixture containing DIG-dUTP in addition to the normal deoxynucleotide triphosphates. The labeled PCR product was then purified using a high pure PCR product purification kit (Boehringer Mannheim). The labeled DNA was resuspended in TE buffer and stored at $-20^{\circ} \mathrm{C}$ until used.

Preparation of shrimp fecal samples: Shrimp feces were prepared in 2 ways. Some batches were collected from 5 shrimp ponds in the Rajburi province and preserved in lysis buffer (50 mM Tris- $\mathrm{HCl} \mathrm{pH}$ 9.0, $100 \mathrm{mM}$ EDTA, $50 \mathrm{mM} \mathrm{NaCl}, 2 \%$ SDS, $1 \mu \mathrm{g}$ Proteinase K) at approximately $100 \mathrm{mg}$ of feces in $200 \mu \mathrm{l}$ of lysis buffer. This was transferred to a $1.5 \mathrm{ml}$ microfuge tube, boiled for $10 \mathrm{~min}$ and centrifuged at $2100 \times g$ for $15 \mathrm{~s}$. The supernatant was collected and $5 \mu \mathrm{l}$ used directly as the DNA template in the optimized PCR assay and in dot blot hybridization tests. Positive controls were prepared by adding HPV DNA to the supernatant followed by serial 10-fold dilution from $100 \mathrm{pg}$ to $0.1 \mathrm{fg}$.
Other batches of feces were prepared by homogenizing approximately $100 \mathrm{mg}$ shrimp feces in $200 \mu \mathrm{l}$ of solution containing $0.05 \% \mathrm{NaOH} / 0.025 \%$ SDS (Kiatpathomchai et al. 2001). Because no HPV-infected shrimp feces were available, HPV-positive feces samples were prepared from virus free feces by addition of HPV DNA. HPV DNA from a 5 ng stock was added to samples of feces homogenates at final concentrations from $100 \mathrm{pg}$ to $0.1 \mathrm{fg}$ per $100 \mathrm{mg}$ sample. These samples were then boiled for $10 \mathrm{~min}$ and centrifuged at $2100 \times g$ for $15 \mathrm{~s}$ to remove debris. The supernatant was used in aliquots of $5 \mu \mathrm{l}$ for optimized PCR and dot blot hybridization tests.

PL sample preparation: PL were also prepared in both lysis buffer and NaOH/SDS solutions. For lysis buffer, $20 \mathrm{PL}$ (at Stages 10 to 15 , i.e. $\mathrm{PL}_{10}$ to $\mathrm{PL}_{15}$ ) were collected and transferred to a $1.5 \mathrm{ml}$ microfuge tube containing $1 \mathrm{ml}$ of lysis buffer as described above. Then, they were homogenized, boiled for 10 min and centrifuged at $5000 \mathrm{rpm}$ for $15 \mathrm{~s}$. (Positive controls were prepared by the addition of HPV DNA from $1 \mathrm{ng}$ to $0.1 \mathrm{fg}$ to homogenates.) Aliquots (5 $\mu \mathrm{l})$ of some of the supernatants served as direct DNA templates for PCR assays and dot blot hybridization tests. Another portion of the supernatant was used for DNA extraction.

Phenol-chloroform was added to the supernatant solutions in equal volume and mixed by inversion. The solutions were then centrifuged at $8400 \times g$ for $5 \mathrm{~min}$. The upper layer was removed and mixed with an equal volume of chloroform-isoamylalcohol (24:1). The solution was mixed by inversion and then centrifuged at $8400 \times g$ for $5 \mathrm{~min}$. The upper solution was removed for precipitation by addition of 2 vol of absolute ethanol. The precipitated DNA was then resuspended in TE buffer $\mathrm{pH} 8(100 \mu \mathrm{l})$. These DNA extracts were used as templates $(5 \mu \mathrm{l})$ for PCR assays.

Other samples of $20 \mathrm{PL}_{10}$ to $\mathrm{PL}_{15}$ were homogenized in a $500 \mu \mathrm{l}$ solution containing $0.05 \% \mathrm{NaOH} / 0.025 \%$ SDS until finely dispersed. HPV DNA from $1 \mathrm{ng}$ to $0.1 \mathrm{fg}$ was then mixed with these PL homogenates followed by boiling for $10 \mathrm{~min}$ and centrifugation at $5000 \mathrm{rpm}$ for $15 \mathrm{~s}$. Aliquots $(5 \mu \mathrm{l})$ of the resultant supernatants were then used as templates for PCR assays and dot blot hybridization tests.

Dot blot hybridization: DNA solutions were denatured by boiling for $10 \mathrm{~min}$ and transferred to ice for $5 \mathrm{~min}$. Denatured DNA solution ( $5 \mu \mathrm{l}$ ) was loaded onto Nylon membranes using a dot blot apparatus (Biodot, Biorad) or carefully dotted by hand. DIG-labeled probe prepared as described above was diluted in buffer to a concentration of $10 \mathrm{ng} \mathrm{ml}^{-1}$ and incubated with membranes overnight at $68^{\circ} \mathrm{C}$ for hybridization. Positive hybridization was detected colorimetrically as instructed in the Genius ${ }^{\mathrm{TM}}$ kit manual. 


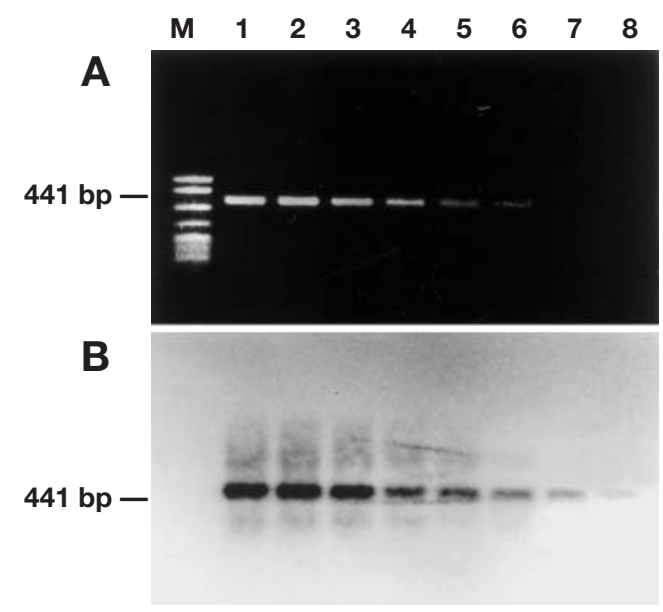

Fig. 1. Sensitivity of PCR using the H441 primers set. (A) Agarose gel of 10-fold serially diluted purified hepatopancreatic parvovirus from Penaeus monodon (HPVmon) DNA used as template under optimized PCR conditions. (B) Southern blot hybridization of agarose gel from (A) hybridized with digoxygenin-labeled PH441 probe. Lane M = pBR322 DNAMsp I digested DNA size marker; Lanes 1 to $8=$ purified HPVmon DNA template at concentrations of 100, 10 and $1 \mathrm{pg}$, and $100,10,1,0.1$ and $0.01 \mathrm{fg}$, respectively. The amplicon at $1 \mathrm{fg}$ of HPVmon DNA template is not distinctly visible in the photograph but could be seen clearly in the actual gel

In situ hybridization: HPVmon specimens were preserved in Davidson's fixative and prepared for histological examination as described by Bell \& Lightner (1988). The embedded samples were cut to 5-6 $\mu \mathrm{m}$ thickness and processed on Fisher ProbeOn Plus microscope slides for in situ hybridization using DIGlabeled probe (10 $\mathrm{ng} \mathrm{ml}{ }^{-1}$ at $42^{\circ} \mathrm{C}$ overnight) as instructed in the Genius ${ }^{\mathrm{TM}}$ kit manual.

Results. PCR optimization: Best PCR results were obtained using: $1 X$ PCR buffer with $1.5 \mathrm{mM}$ of $\mathrm{MgCl}_{2}$, $200 \mu \mathrm{M}$ each of dATP, dTTP, dCTP and dGTP, $0.2 \mu \mathrm{M}$ each of primer $\mathrm{H} 441 \mathrm{~F}$ and H441R, 1.25 unit of Taq DNA polymerase, 1 to $10 \mathrm{ng}$ DNA template and double distilled water to adjust the final volume to $50 \mu \mathrm{l}$ before PCR with 1 cycle of $95^{\circ} \mathrm{C}$ for $5 \mathrm{~min}$, and 35 cycles of denaturation at $95^{\circ} \mathrm{C}$ for $1 \mathrm{~min}$, annealing at $60^{\circ} \mathrm{C}$ for $1 \mathrm{~min}$, extension at $72^{\circ} \mathrm{C}$ for $1 \mathrm{~min}$ and a final extension at $72^{\circ} \mathrm{C}$ for $7 \mathrm{~min}$.

PCR specificity and sensitivity: Under optimized PCR conditions, H441F and H441R primers did not generate any amplicon with purified template DNA from WSSV, IHHNV, HPVchin (DiagXotics, positive control), Vibrio parahemolyticus and HPVmon. They gave a 441 bp product only with templates containing HPVmon DNA or purified plasmid containing the $732 \mathrm{bp}$ HPVmon fragment from which they were derived. The lowest amount of the purified HPVmon DNA template that could be detected was $1 \mathrm{fg}$, which gave a faint product at 441 bp (Fig. 1). By Southern blot hybridization, the $441 \mathrm{bp}$ amplicon could be detected by DIG-labeled PH441 probe at $0.01 \mathrm{fg}, 100$ times lower concentration than could be visualized in the agarose gel (Fig. 1).

PCR detection of HPV in fecal and PL samples: HPVmon DNA spiked samples of shrimp feces and PL preserved in lysis buffer gave no PCR amplicon when supernatant solution was used directly as the DNA template. In contrast, supernatant solution from feces and PL samples homogenized in $0.025 \% \mathrm{NaOH} /$ $0.0125 \%$ SDS used directly as DNA template did give PCR amplicons detectable in agarose gels when $100 \mathrm{fg}$ or more HPVmon DNA was added. Although supernatant solutions from PL homogenates in lysis buffer could not be used directly as template for PCR assays, DNA extraction of these supernatant solutions did give positive results in agarose gels with $1 \mathrm{pg}$ or more of spiked HPVmon DNA.

Specificity and sensitivity of $\mathrm{PH} 441$ probe: By dot blot hybridization at $65^{\circ} \mathrm{C}$, the DIG-labeled $\mathrm{PH} 441$ probe gave an intense positive hybridization reaction with 100 pg HPVmon DNA but not with 10 ng DNA for WSSV, Vibrio parahemolyticus or HPVmon (Fig. 2). Nor did it give a positive reaction with DNA extracts from shrimp food, shrimp feces or PL free of HPV. With serial 10-fold dilutions of HPVmon DNA prepared

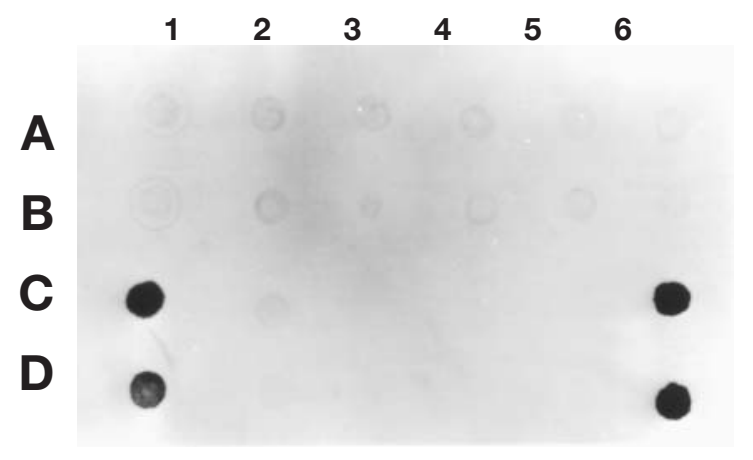

Fig. 2. Dot blot detection of HPVmon DNA in fecal and postlarvae (PL) samples using digoxygenin-labeled PH441 probe. Under the high stringency conditions used, the probe reacted with HPVmon DNA only. Lane 1, A,B = supernatant of HPVfree shrimp feces in $\mathrm{NaOH} / \mathrm{SDS}$; Lane 2, A,B = DNA extract of HPV-free shrimp feces in lysis buffer; Lane 3, A,B = supernatant of HPV-free shrimp feces boiled in distilled water; Lane $4, \mathrm{~A}, \mathrm{~B}=$ DNA extract of HPV-free PL homogenate in lysis buffer; Lane 5, A,B = supernatant of HPV-free PL homogenate in $\mathrm{NaOH} / \mathrm{SDS}$; Lane $6, \mathrm{~A}, \mathrm{~B}=$ DNA extract of shrimp food; Lane 1, C,D = 100 pg of HPVmon DNA in shrimp feces; Lane 2, C,D = shrimp pond water; Lane 3, C = $10 \mathrm{ng}$ of DNA extracted from normal shrimp (Penaeus monodon); Lane $4, \mathrm{C}=10 \mathrm{ng}$ of yellow head virus RNA; Lane 5, C = blank; Lane 3, D = $10 \mathrm{ng}$ of DNA from the bacterium Vibrio parahemolyticus; Lane $4, \mathrm{D}=10 \mathrm{ng}$ of DNA from white spot syndrome virus; Lane 6, C,D = 100 pg of HPVmon DNA 
from $100 \mathrm{pg}$ to $1 \mathrm{fg}$, the lowest concentration giving a visible signal was $10 \mathrm{fg}$.

HPV detection in fecal and PL samples by dot blot hybridization: The shrimp feces and PL samples used in these tests were the same as those used for the PCR tests. Thus, supernatants of feces and PL spiked with various HPV DNA quantities from $100 \mathrm{pg}$ to $10 \mathrm{fg}$ were blotted onto a nylon membrane and hybridized with PH441 probe. A strong intense signal was visible down to $1 \mathrm{pg}$ in feces samples and $0.1 \mathrm{pg}$ in PL samples. There were no positive signals with shrimp feces and PL not spiked with HPV DNA, or with shrimp culture water or shrimp feed.

In situ hybridization: All histological samples were first screened by H\&E staining for histopathology characteristic of HPV infection. The histological slides of HPV-infected, monodon baculovirus (MBV)-infected, WSSV-infected, IHHNV-infected and normal HPVmon were hybridized with PH441 probe. This probe gave a blue-black staining reaction with HPV-infected nuclei of hepatopancreatic cells from HPVmon (Fig. 3), whereas no signals were found in slides prepared from normal shrimp or shrimp infected with other viruses. Most HPV intranuclear inclusion bodies gave a strong signal with the probe, but some gave a weak signal. In contrast, the DIG-HPV probe obtained from DiagXotics gave either weak or no signals with HPVinfected tissue in Thai HPVmon.

Discussion. For diagnosis of HPV infections, classical histopathology with H\&E staining or transmission electron microscopy (Lightner 1996) is complicated, time consuming and requires experience for interpretation. A simple method using Giemsa-stained impression smears of the hepatopancreas (Lightner et al. 1993) is more convenient and rapid; however, this still requires

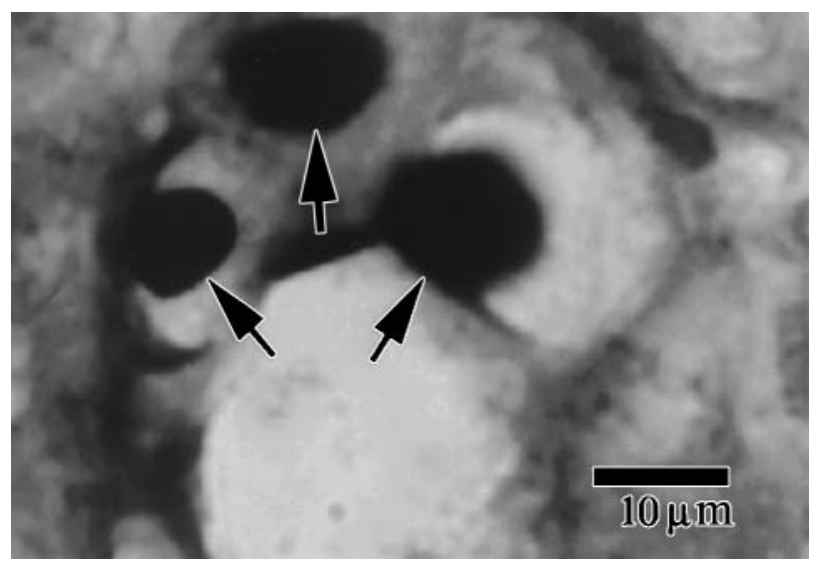

Fig. 3. In situ hybridization using DIG-labeled PH441 probe. High magnification (100×) view showing positive hybridization signals (arrows) in hypertrophied nuclei of hepatopancreatic cells of Penaeus monodon containing inclusion bodies of HPV experience for interpretation and may be difficult with light infections. In addition, the methods require destruction or biopsy of tested shrimp. PCR assay is one possible alternative for easy and rapid detection of HPV with high sensitivity and specificity. It could be suitable for screening whole PL before stocking or broodstock and pond-reared shrimp via their feces. PCR detection methods for HPVchin have been published by Pantoja \& Lightner (2000) and are available. A PCR method has also been published for HPVmon (Sukhumsirichart et al. 1999). However, all of these methods present some difficulties for HPVmon. The method described by Pantoja \& Lightner (2000) gives a different amplicon (732 bp) with HPVmon than with HPVchin (350 bp) and with lower sensitivity of detection (Phromjai et al. 2001). The method from Sukhumsirichart et al. (1999) gives a very small amplicon of 130 bp that may sometimes be confused with primerdimers in agarose gels of PCR reaction products. The method from Pantoja \& Lightner (2000) was designed based on sequences of HPVchin and has not been confirmed for use with HPVmon.

The primer pair H441F and H441R overcomes these problems and the limit of detection was $1 \mathrm{fg}$ of HPVmon DNA or approximately 340 virions; a sensitivity equivalent to that for previously published primers for HPVmon (Sukhumsirichart et al. 1999) and approximately 1000-times higher than that obtained using the commercial primers designed for HPVchin. On the other hand, we did not have access to full length HPVchin DNA, and although the primers gave no product with the HPVchin-positive control from the DiagXotics kit used, it is possible that they would give a product with whole HPVchin DNA. However, based on the major part of the HPVchin DNA sequence at GenBank (AY008257), the sequence for primer H441F differs by only 3 bases (positions 9, 10 and 14 from its 3' end) from the corresponding sequence of HPVchin, while the sequence for H441R is identical. Based on this, one might expect some amplification, especially at high template concentrations. Thus, the primers described herein should not be considered as differential primers for HPVmon and HPVchin, but as convenient tools for detection of HPVmon in Thailand and perhaps elsewhere in Southeast Asia. The DIG-labeled PH441 probe produced by PCR labeling would also be useful for detection of HPVmon by dot blot assay or in situ DNA hybridization in Thailand and perhaps elsewhere in Southeast Asia.

No PCR product was obtained directly from any fecal or PL sample stored in lysis buffer, including positive control samples spiked with HPVmon. In contrast, homogenization of fecal and PL samples in $0.025 \%$ $\mathrm{NaOH} / 0.0125 \%$ SDS did give positive results for approximately 0.01 to $0.1 \mathrm{pg}$ HPVmon DNA (about 
3400 to 34000 viral targets, respectively). Similar success with this extraction buffer has been reported for PCR detection of WSSV (Kiatpathomchai et al. 2001, Thakur et al. 2002). It has been reported that SDS can inhibit PCR at final concentrations greater than $0.01 \%$ (Rolfs et al. 1992) and that $0.01 \%$ SDS can reduce Taq DNA polymerase activity to $10 \%$ (Gelfand 1989). With the NaOH/SDS extraction solution, the final concentration of SDS in the $50 \mu \mathrm{l}$ PCR reaction solution would have been $0.001 \%$. Thus, the false negative results for HPV detection in feces and PL stored in lysis buffer possibly resulted from the SDS it contained (i.e. $2 \%$ SDS), since it would have resulted in $0.2 \%$ SDS in the $50 \mu \mathrm{l}$ PCR reaction solution. In addition, it is known that negative results may arise from other inhibitory substances (Wilde et al. 1990) that might also be present in fecal or PL specimens and be extracted with higher concentrations of SDS. On the other hand, the lysis buffer was convenient in that homogenized samples could be stored for more than $2 \mathrm{yr}$ at room temperature without significant degradation of high molecular weight DNA, and this allowed easy collection of large numbers of samples for later analysis or collection in remote areas without the need for refrigeration. The disadvantage was that the DNA subsequently had to be extracted from the homogenate prior to PCR assay and that fresh samples had to be processed immediately.

DNA extraction prior to PCR assay gave a $441 \mathrm{bp}$ product for PL samples spiked with as little as $1 \mathrm{pg}$ HPVmon DNA, meaning that a minimum of approximately 340000 virions of HPV would be needed in the original sample for virus detection by this method. In contrast, HPVmon in non-extracted samples in SDS/ $\mathrm{NaOH}$ solution could be detected at as little as $0.1 \mathrm{pg}$ of spiked HPVmon DNA or the equivalent of 34000 virions in the sample. Thus, the DNA extraction process was approximately 10 times less sensitive for HPVmon detection than the non-DNA extraction method, suggesting that viral DNA was lost disproportionately by approximately $90 \%$ during the DNA extraction steps. Although the amount of DNA lost might depend on individual extraction techniques, it appeared that the non-extraction method should be favored wherever possible to avoid any risk of loss leading to false negative assay results or misinterpretation of infection level. On the other hand, extraction may be necessary if the presence of inhibitors is suspected or confirmed by the inclusion of PCR controls.

When dot blot hybridization was applied with field samples of shrimp feces and PL, the smallest amount of spiked HPVmon DNA that gave a clear positive signal was approximately 0.1 to $1 \mathrm{pg}$. This was 10 to 100 times less sensitive than dot blot detection using purified HPVmon DNA. It is possible that cell debris or artifacts in the feces and PL solutions negatively affected probe hybridization. Another problem with dot blot detection was weak background signals sometimes seen and probably due to non-specific DNA binding to unknown substances in the samples. This would not lead to false positive results for heavy infections because of the inclusion of negative controls such as fecal or PL samples free of HPV together with sharply contrasting positive control samples. On the other hand, light infections would clearly go undetected and so the method would not be suitable for screening of carriers with low viral loads.

Acknowledgements. The authors would like to thank the National Center for Genetic Engineering and Biotechnology (BIOTEC), Thailand, for partial support to carry out this work. Thanks also to Dr. Wasana Sukumsirichart for providing purified HPVmon virus and to technical staff of Department of Pathobiology, Faculty of Science, Mahidol University for tissue section preparation.

\section{LITERATURE CITED}

Bell TA, Lightner DV (1988) A handbook of normal shrimp histology. World Aquaculture Society, Baton Rouge, LA

Flegel TW, Fegan DF, Vuthikornudomkit S, Sriurairatana S, Boonyaratpalin S, Chantanachookhin C, Vickers JE, Macdonald OD (1992) Occurrence, diagnosis and treatment of shrimp disease in Thailand. In: Fulks W, Main KL (eds) Diseases of cultured penaeid shrimp in Asia and the United States. Oceanic Institute, Honolulu, p 57-112

Flegel TW, Thamavit V, Passarawipas T, Alday-Sanz V (1999) Statistical correlation between severity of hepatopancreatic parvovirus (HPV) infection and stunting of farmed black tiger shrimp (Penaeus monodon). Aquaculture 174: 197-206

Gelfand DH (1989) Taq DNA polymerase. In: Erlich HA (ed) PCR technology: principles and applications for DNA amplification. Stockton Press, New York, p 16-22

Kiatpathomchai W, Boonsaeng V, Tassanakajon A, Wongteerasupaya C, Jitrapakdee S, Panyim S (2001) A nonstop, single tube, semi-nested PCR technique for grading the severity of white spot syndrome virus infections in Penaeus monodon. Dis Aquat Org 47:235-239

Lightner DV, Redman RM, Moore DW, Park MA (1993) Development and application of a simple and rapid diagnostic method to study hepatopancreatic parvovirus of penaeid shrimp. Aquaculture 116:15-23

Lightner DV (1996) A handbook of pathology and diagnostic procedures for diseases of cultured panaeid shrimp. World Aquaculture Society, Baton Rouge, LA

Mari J, Lightner DV, Poulos BT, Bonami JR (1995) Partial cloning of the genome of an unusual shrimp parvovirus (HPV): use of gene probes in disease diagnosis. Dis Aquat Org 22:129-134

Pantoja CR, Lightner DV (2000) A non-destructive method based on the polymerase chain reaction for detection of hepatopancreatic parvovirus (HPV) of penaeid shrimp. Dis Aquat Org 39:177-182

Pantoja CR, Lightner DV (2001) Detection of hepatopancreatic parvovirus (HPV) of penaeid shrimp by in situ hybridization at the electron microscope level. Dis Aquat Org 44:87-96 
Phromjai J (1999) The application of gene probes to detect HPV of Penaeus monodon by in situ hybridization, dot blot hybridization and PCR amplification. MSc thesis, Mahidol University, Bangkok

Phromjai J, Sukhumsirichart W, Pantoja C, Lightner DV, Flegel TW (2001) Different reactions obtained using the same DNA detection reagents for Thai and Korean hepatopancreatic parvovirus of penaeid shrimp. Dis Aquat Org 46:153-158

Rolfs A, Schuller I, Frinckh U (1992) Substances affecting PCR: inhibition and enhancement. In: PCR: clinical diagnostics and research. Springer-Verlag, Berlin, p 99-111

Sukhumsirichart W, Wongteerasupaya C, Boonsaeng V,
Editorial responsibility: Carey Cunningham, Aberdeen, Scotland, UK
Panyim S, Sriurairatana S, Withyachumnarnkul B, Flegel TW (1999) Characterization and PCR detection of hepatopancreatic parvovirus (HPV) from Penaeus monodon in Thailand. Dis Aquat Org 38:1-10

Thakur PC, Corsin F, Turnbull JF, Shankar KM and 5 others (2002) Estimation of prevalence of white spot syndrome virus (WSSV) by polymerase chain reaction in Penaeus monodon postlarvae at time of stocking in shrimp farms of Karnataka, India: a population-based study. Dis Aquat Org 49:235-243

Wilde J, Eiden J, Yolken R (1990) Removal of inhibitory substances from human fecal specimens for detection of group A rotaviruses by reverse transcriptase and polymerase chain reactions. J Clin Microbiol 28:1300-1307

Submitted: January 28, 2002; Accepted: May 28, 2002

Proofs received from author(s): September 6, 2002 